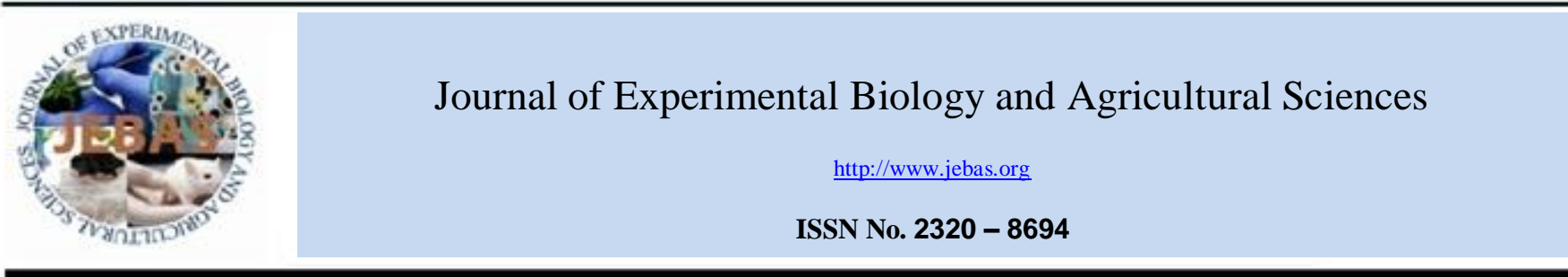

\title{
EFFECT OF STORAGE PERIOD ON VARIOUS PHYSIOLOGICAL, BIOCHEMICAL AND ENZYMATIC PARAMETERS OF GUAVA (Psidium guajava L.) FRUIT
}

\author{
MAHAJAN Bal Vipan Chander ${ }^{1}$, GILL Karanbir Singh ${ }^{2}$, DHALIWAL Harvinder $\operatorname{Singh}^{2}$ \\ ${ }^{1}$ Punjab Horticultural Postharvest Technology Centre \\ ${ }^{2}$ Department of Fruit SciencePunjab Agricultural University, Ludhiana-141004, India
}

Received - July 20, 2017; Revision - October 21, 2017; Accepted - December 08, 2017

Available Online - December 27, 2017

DOI: http://dx.doi.org/10.18006/2017.5(6).846.851

\section{KEYWORDS \\ Storage time \\ Quality \\ Physiological \\ Biochemical \\ Enzymatic activity \\ Guava}

\begin{abstract}
Guava is a climacteric fruit, undergoes rapid metabolic activities and hence has short shelf life. Therefore in order to ascertain its storage life, the physiological, biochemical and enzymatic changes during storage were studied. The data revealed that during storage the physiological loss in weight of fruit increased, whereas firmness, titratable acidity, ascorbic acid, total phenols and pectin content decreased. The total soluble solids, total sugars content increased up to 14 days of storage and thereafter declined. The activity of pectin methyl esterase was quite low at the time of harvest, increased commensurate with the storage period up to 14 days and then declined towards the end of storage period leading to softening of fruit.
\end{abstract}

* Corresponding author

E-mail: mahajanbvc@gmail.com (MAHAJAN Bal Vipan Chander)

Peer review under responsibility of Journal of Experimental Biology and Agricultural Sciences.

Production and Hosting by Horizon Publisher India [HPI] (http://www.horizonpublisherindia.in/).

All rights reserved.
All the article published by Journal of Experimental Biology and Agricultural Sciences is licensed under a Creative Commons Attribution-NonCommercial 4.0 International License Based on a work at www.jebas.org.

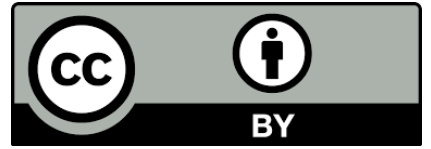




\section{Introduction}

Ripening is a dramatic event in the life of a fruit. It is generally agreed that fruit ripening is a biological active process, often involving high metabolic activity and ultimately deterioration of fleshy organs (Gapper et al., 2013). It is an important process that renders the fruit attractive, palatable also adds value to fruit making them adequate for human consumption. However, at advanced stages the ripening may also render the fruit unmarketable by inducing undesirable flavours and excessive pulp softening thereby reducing its quality and shelf life (Bapat et al.,2010). The important events that occur during ripening and senescence of fruit reflect the modification of cell wall ultrastructure leading to tissue softening, alterations in pigment biosynthesis, synthesis and accumulation of aromatic volatiles and ultimately increased susceptibility to post-harvest pathogens (Rhodes, 1980).

Guava is popular among farmers, traders and consumers as highly nutritious fruit (Singh, 2005). It is a climacteric fruit (Akamine \& Goo 1979), ripens rapidly after harvest and therefore has short shelf-life, making its marketing more difficult. The fact that the guava is highly perishable due to its climacteric nature, has made it necessary to store fruits at optimum temperature to prolong its shelf life in order to reduce postharvest losses and favour its commercialization in distant markets (Mahajan et al., 2009). In the present investigation an attempt has been made to study the various physiological, biochemical and enzymatic changes occurring during storage of guava fruits in order to ascertain its marketable storage life with acceptable quality.

\section{Materials and Methods}

\subsection{Sample collection}

'Allahabad Safeda' guava fruits were harvested at firm mature stage during $3^{\text {rd }}$ week of December from 15 years old well managed orchard. For the storage study only the uniform, healthy and blemish free fruits were selected. The fruits were packed in corrugated fibre board (CFB) boxes along with newspaper lining and stored in walk-in-cold room maintained at $6-8^{\circ} \mathrm{C}$ temperature and $90-95 \%$ RH. The experiment was laid out in Randomized Block Design with three replications and each treatment comprised of $5 \mathrm{~kg}$ fruits. The fruits were analyzed at 7 days interval for various physiological, biochemical and enzymatic changes during storage.

\subsection{Assessment of physico-chemical parameters}

The physiological loss in weight (PLW) was worked out as percentage reduction in initial weight at weekly interval. Fruit firmness was recorded using $8 \mathrm{~mm}$ stainless steel probe penetrometer (Model FT-327, USA) and the pressure readings were notes as pound force (lb force). The consumer acceptance/ palatability rating of the stored fruits was assessed using a 9 point hedonic scale on the basis of appearance and edible quality by a panel of ten judges as explained by Amerine et al. (1965). Temperature compensated digital refractometer was used to estimate the TSS content of the stored fruits. The titratable acidity, sugars and vitamin $\mathrm{C}$ were estimated using the standard procedures as per AOAC (2010). The total phenols and pectin content were determined as per methods adopted by Bray \& Thorpe (1954) and Ruck (1963).

\subsection{Pectin Methyl Esterase Enzyme bioassay}

For enzyme extraction, $20 \mathrm{~g}$ fruit pulp was macerated in $60-100$ $\mathrm{ml}$ solution of $0.15 \mathrm{M} \mathrm{NaCl}$. The mixture was filtered through cheese cloth and centrifuged for $30 \mathrm{~min}$ at $4{ }^{\circ} \mathrm{C}$ and $2000 \mathrm{rpm}$, the supernatant was used as enzyme source. The $\mathrm{pH}$ of the $\mathrm{NaCl}$ solution was maintained constantly at 7.0 for $0.15 \mathrm{M}$ for maximum PME activity as explained by Castaldo et al., (1989); Denes et al., (2000) and Contreras-Esquivel et al., (1999) the pH and salt concentration are directly correlated. The increase in acidity due to PME mediated hydrolysis of pectin was measured and was used to work out the enzyme activity (Mahadevan \& Sridhar,1982). PME activity was expressed as (units/ml juice) representing milli equivalents of esters hydrolyzed per min per $\mathrm{ml}$ of juice. The units per milliliter were multiplied by 1,000 for easy interpretation as described by Balaban et al (1991).

\subsection{Experimental design and statistical analysis}

The experiment was laid out in completely randomized design with 3 replications and each replication comprised of $5 \mathrm{~kg}$ fruits. Data were analyzed for variance by using the SAS (V 9.3, SAS Institute Inc., and Cary, NC, USA) package.

\section{Results and Discussion}

\subsection{Physiological loss in weight (PLW)}

The percent PLW of the fruits increased throughout the storage period. The weight loss was gradual at the initial storage interval but became progressive as the storage period advanced and ranged from 1.10 to $5.30 \%$ (Figure 1). Fruit weight loss during storage is attributed to loss of moisture by evapo-transpiration and respiration, respectively (Siddiqui et al., 1991). Weight loss affects the visual appearance and texture of the fruits and causes a reduction in saleable weight. It has been pointed out that losses of less than $5 \%$ in weight do not detract materially and are of little economic significance in majority of horticultural crops. However, the water loss above 5\% is generally considered to cause a noticeable loss of quality and value (Kays, 1991; Kader, 2002). 


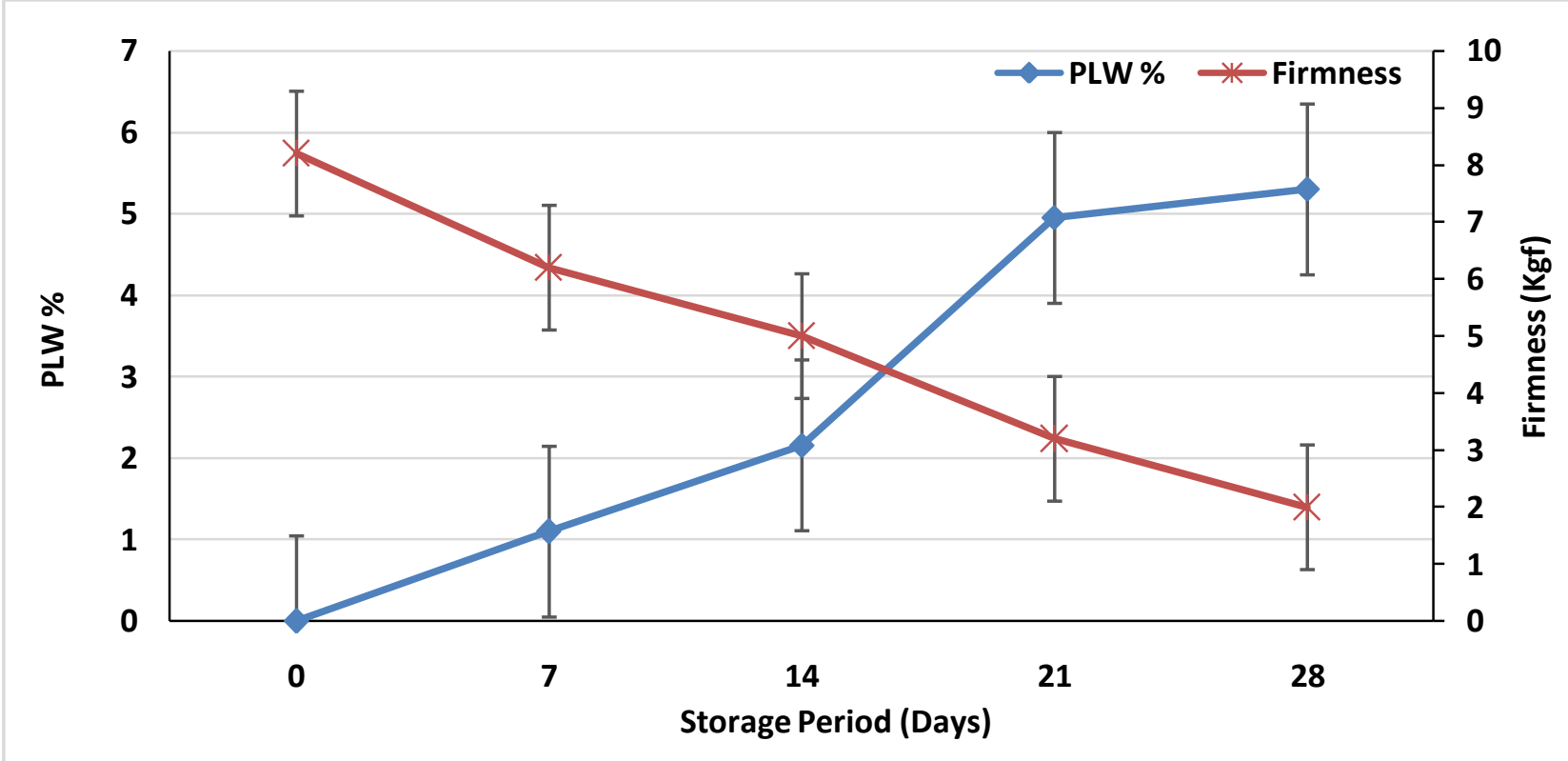

Figure 1 Changes in weight loss and firmness in guava during storage

\subsection{Firmness}

The fruit firmness registered a declining trend throughout the storage period (Figure 1). It was noticed that the guava fruits registered a firmness of $8.2 \mathrm{Kg}$ force before storage of fruits which subsequently declined to $2 \mathrm{Kg}$ force after 28 days of storage. The decline in firmness was gradual initially up to 2 weeks, when fruits registered firmness of $5 \mathrm{~kg}$ force but later on the decline was sharp and the puncture force of $2 \mathrm{Kg}$ force was observed after 28 days of storage. Fruit firmness is one of the most important attributes in determining the post- harvest quality (Maude \& Bouageois, 2013). The decline in firmness during storage is mainly caused due to the dissolution of the middle lamella, the reduction of cell-to-cell adhesion and the weakening of parenchyma cell walls as a result of the action of cell wall modifying enzymes leading to shriveling and softening (Paniagua et al., 2014).

\subsection{Total soluble solids and total sugars}

The TSS and total sugars which were fairly low at harvest $(9.4 \%$ and $5.58 \%$ ), increased as the storage advanced and reached a peak value at 14 days of storage $(11.60 \%$ and $6.30 \%)$ and declined thereafter (Figure 2). The increase in TSS and total sugars during storage may be due to hydrolysis of starch into sugars. On completion of hydrolysis of starch, the further increase in TSS/sugars did not occur. Hence decline in these attributes is predictable as these are the prime substrate for respiration of fruits (Smith et al., 2005).

\subsection{Titratable acidity}

A declining trend in the titratable acidity of the fruit during storage was noticed which varied from $0.55 \%$ to $0.26 \%$ (Figure 2). The decline in titratable acidity during ripening and storage might be due to the utilization of organic acids as substrates for respiration (Roth et al., 2007)

\subsection{Ascorbic acid}

The ascorbic acid content of guava fruits decreased significantly with the advancement of storage period (Figure 3). The ascorbic acid was found to be $180 \mathrm{mg} / 100 \mathrm{~g}$ pulp at the time of harvest, which further decline to $110 \mathrm{mg} / 100 \mathrm{~g}$ pulp during storage. The decrease in ascorbic acid during storage may be due to the oxidation of L-ascorbic acid into dehydroascorbic acid (Mapson, 1970).

\subsection{Total phenols}

A continuous decline in the total phenol with the advance in storage period was observed (Figure 3). The maximum level of total phenols (195 mg/ $100 \mathrm{~g}$ pulp) was recorded after harvest, which reduced to $105 \mathrm{mg} / 100 \mathrm{~g}$ pulp at the end of storage period 


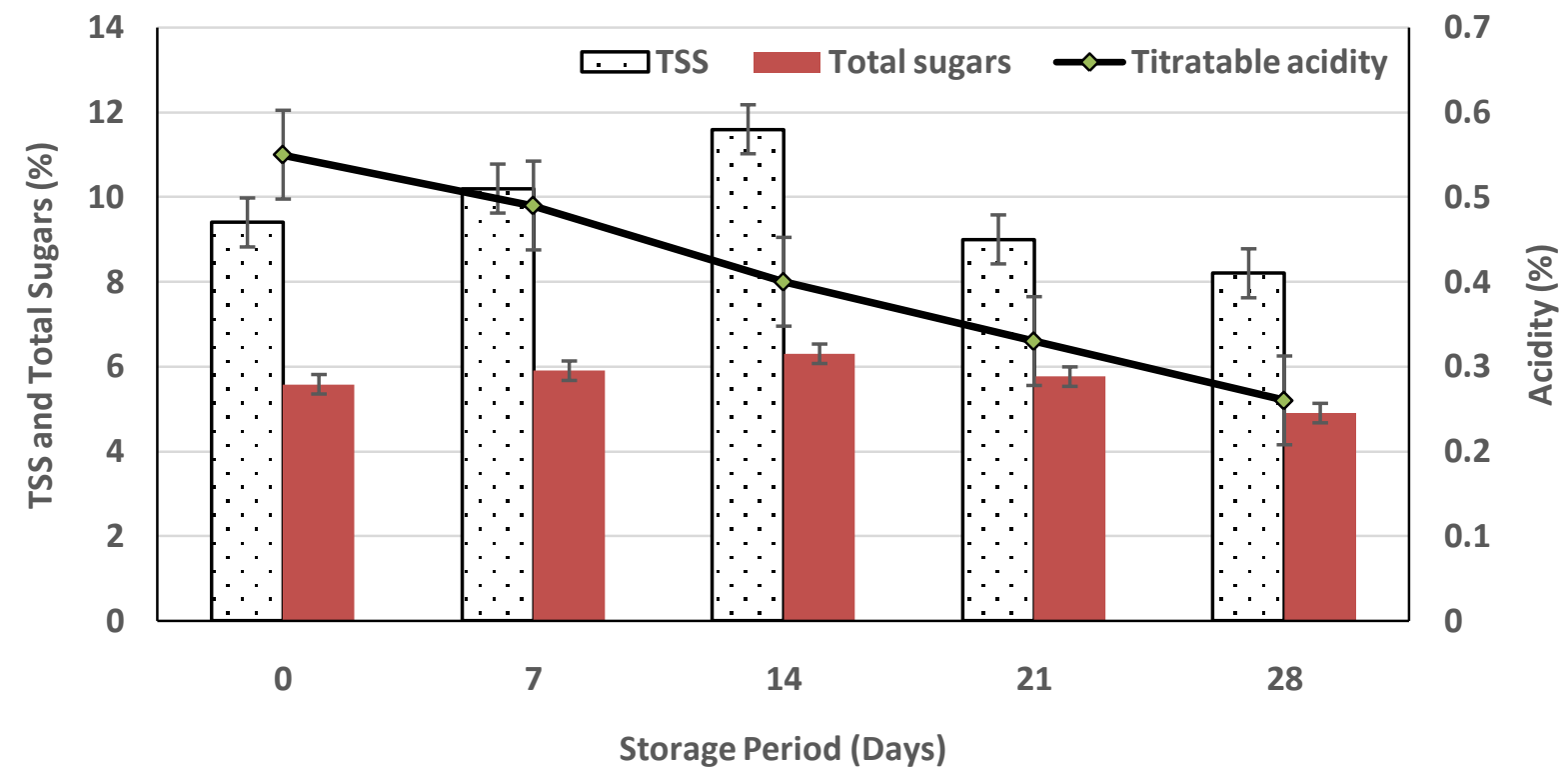

Figure 2 Changes in TSS, total sugars and acidity in guava during storage

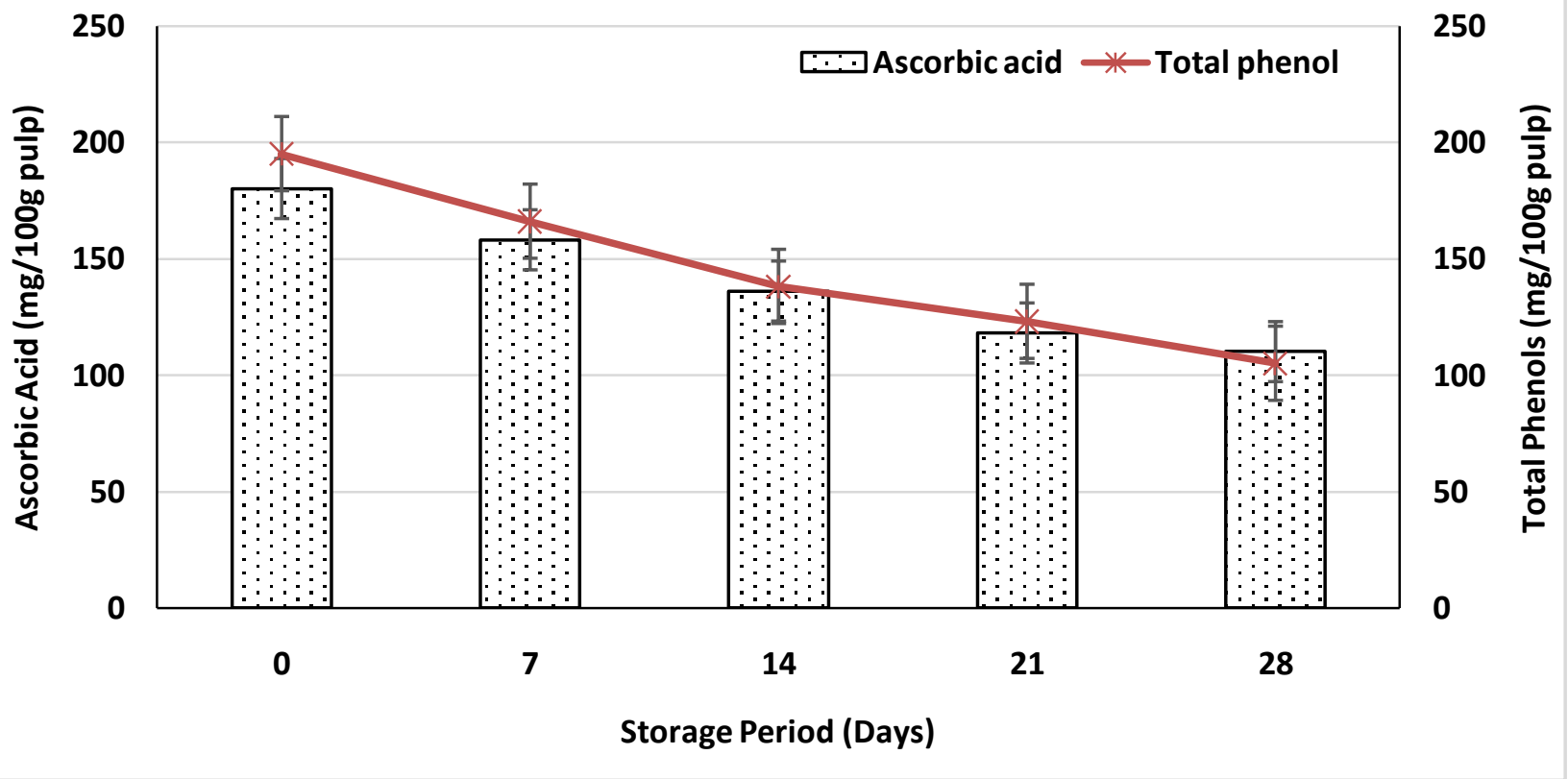

Figure 3 Changes in ascorbic acid and total phenols in guava during storage

Journal of Experimental Biology and Agriculture Science http://www.jebas.org 


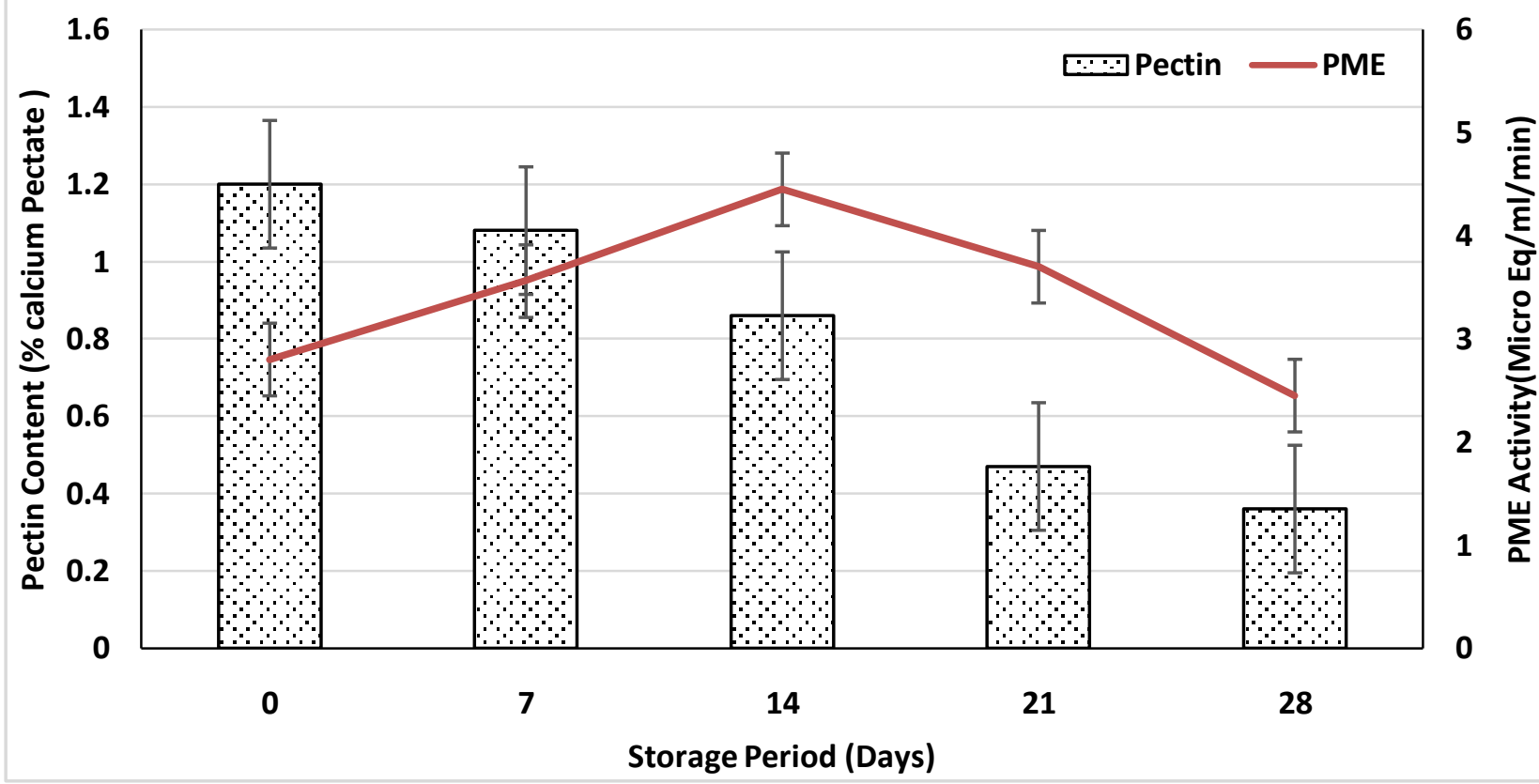

Figure 4 Changes in pectin content and pectin methyl esterase activity in guava during storage

studied. It has been reported that the concentration of phenolics decreased during storage of fruits (Hulme et al., 1971), thereby making the fruit susceptible to pathological breakdown.

\subsection{Pectin}

There was a gradual linear decline in pectin content with the advance in storage period (Figure 4). The pectin content ranged between 1.20 and 0.36 percent calcium pectate from harvest upto 28days of storage. The decline in pectin content during storage is due to conversion of insoluble protopectin into soluble pectin. The degradation of pectin during storage occurs due to solubilization and depolymerization of pectins leading to cell wall dissembly and this process apparently leads to softening of fruits (Brummel, 2006).

\subsection{Pectin methyl esterase activity}

A perusal of data on PME activity reveals that it was quite low at the time of harvest, increased commensurate with the storage period upto 14 days and then declined towards the end of sampling (Figure 4). It has been established that textural changes in fruits occur largely as a result of enzyme mediated hydrolysis of cell wall and enzyme reported to be involved with the metabolism of the cell wall, and thus responsible for softening or the solubility of its macromolecules include polygalacturonases (PGS), pectin methyl esterases (PME) and $ß$-galactosidase ( $\beta$-gal)
(Brummell, 2006). Softening of fruit during ripening is normally accompanied by an increase in the concentration of soluble pectic polysaccharides (Denes et al., 2000).

\section{Conclusions}

Guava is a perishable fruit and has very short shelf life under ambient conditions. The results indicated that guava fruits can be stored for two weeks at $6-8^{0} \mathrm{C}$ and $90-95 \% \mathrm{RH}$ with acceptable quality.

\section{Conflict of interest}

Authors would hereby like to declare that there is no conflict of interests that could possibly arise.

\section{References}

Akamine EK, Goo T (1979) Respiration and ethylene production in fruits of species and cultivars of Psidiumand species of Eugenia. Journal of American Society of Horticulture Science 104:632-635.

Amerine MA, Pangborn RM, Roessler EB (1965) Principles of sensory evaluation of food. Academic Press, London, Pp 5.

AOAC (2010) Official methods of analysis. Association of Official Analytical Chemists, Washington DC. 
Balaban MO, Arreola AG, Marshall M, Peplow A, Wei CI, Cornel J (1991) Inactivation of pectinesterase in orange juice by supercritical carbon dioxide. Journal of Food Science 56:743-746.

Bapat VA, Trivedi PK, Ghosh A, Sane VA, Ganapathi TR, Nath P (2010) Ripening of fleshy fruit: molecular insight and the role of ethylene. Biotechnology Advances 28:94-107.

Bray HG, Thorpe WU (1954) Analysis of phenolics. In: Glick D (Ed.) Methods of Biochemical Analysis. Interscience Publishers Inc, New York, Pp 27-52.

Brummell DA (2006) Cell wall disassembly in ripening fruit. Functional Plant Biology 33: 103-119.

Castaldo D, Quagliuolo L, Servillo L, Balestrieri C, Giovanne A (1989) Isolation and characterization of pectin methylesterase from apple fruit. Journal of Food Science 54:653-655.

Contreras-Esquivel JC, Correa-Robles C, Aguilar CN, Rodriguez J, Romero J, Romero J, Hours RA (1999) Pectinesterase extraction fromMexican lime (Citrus aurantifolia Swingle) and prickly pear (Opuntia ficus indica L.) peels. Food Chemistry 65:153-156.

Denes JM, Baron A Drilleau JF (2000). Purification, properties and heat inactivation of pectinmethylesterase from apple (cv Golden Delicious). Journal of Science for Food and Agriculture 80:1503-1509.

Gapper NE, Mcquinn RP, Giovannoni JJ (2013) Molecular and genetic regulation of fruit ripening. Plant Molecular Biology 82: 575-591.

Hulme AC (1971) The biochemistry of Foods and their Products. Academic Press, London, UK, pp 537-554.

Kader A (2002) Postharvest Biology and Technology: An Overview. In: Kader AA, Kasmire RF, Mitchel G, Reid MS, Somer NF, Thompson JF (Eds.) Postharvest Technology of Horticultural Crops. Division of Agriculture and Natural Resources, University of California, Pp. 39-47

Kays JS (1991) Postharvest physiology of perishable plant products. Van Nostrand Reinhold, New York.

Mahadevan A, Sridhar R (1982) Methods in physiological plant pathology. Sivakami Publication, Madras.

Mahajan BVC, Sharma SR, Dhall RK (2009) Optimization of storage temperature for guava fruits. Journal of Food Science and Technology 46: 604-605.

Mapson LW (1970) Vitamins in fruits. In: Hulme AC (Ed) The biochemistry of fruits and their products Academic, London pp. 369-383.

Maude L Bouageois G (2013) Effect of preharvest weather conditions on firmness of McIntosh apples at harvest time. HortScience 48: 474-480.

Paniagua CP, Sara MVJ, Kirby AR, Quesada MA, Mercado JA (2014) Fruit softening and pectin disassembly: an overview of nanostructural pectin modifications assessed by atomic force microscopy. Annals of Botany 114: 1375-1384.

Rhodes MJC (1980) The maturation and ripening of fruits. In: Thimann KV (Ed), Senescence in Plants, Boca Raton, FL: CRC Press, Pp. 157-205.

Roth E, Berna A, Beullens K, Yarramraju S, Lammertyn J, Schenk A, Nicolai B (2007) Postharvest quality of integrated and organically produced apple fruit. Postharvest Biology and Technology 45: 11-19.

Ruck JA (1963) Chemical Methods for analysis of Fruits ans vegetable Products. Contribution No. B7. Research Station Summerland BC, Research Branch, Department of Agriculture, Canada.

Siddiqui S, Sharma RK, Gupta OP (1991) Physiological and quality response of guava fruits to posture during storage. HortScience 26: 1295-1297.

Smith AM, Zeeman SC, Smith SM (2005) Starch degradation. Annual Review of Plant Biology 56: 73-98.

Singh G (2005) Strategies for improved production in guava. In: Kishun R, Mishra AK, Singh G, Chandra R (Eds.), Proceeding of 1st International guava symposium. CISH, Lucknow, India, pp. 26-39. 